\title{
Karakteristik Sastra Sufi (Content Analysis Karya-karya Sastra Indonesia)
}

\author{
Lidya $\operatorname{Arman}^{1}$ \\ ${ }^{1}$ Fakultas Dakwah dan Ilmu Komunikasi Universitas Islam Negeri Imam Bonjol Padang; \\ lidyaarman4@gmail.com
}

\begin{abstract}
Literary work is an inseparable part of human life. Literature appears along with the history of human existence. In fact, it can be said that from the literature produced, it reflected the support of human civilization. As a social institution, literature reflects the expression of appreciation and inner experience of the narrator or the author of certain authors or situations. Literature always experiences development along with changing times and the emergence of new thoughts in every aspect of life. This also applies in the world of literature. Parallel aspects will show a clear picture of literature from the past until now. Methodologically this research uses library research or library research. The object of the study in this study is Sufi literary works. The approach used in this study is descriptive qualitative, in which this study describes not intended to test certain hypotheses. Literary works with religious characteristics will be able to direct readers to make conscience more serious, pious and conscientious in inner consideration. So that religious works make the reader pensive and template.
\end{abstract}

Key word: literature; Sufi; religious messages

\begin{abstract}
ABSTRAK
Karya sastra merupakan bagian yang tidak dapat dipisahkan dari kehidupan manusia. Kesusastraan muncul bersama dengan sejarah keberadaan manusia. Bahkan dapat dikatakan bahwa dari kesustraan yang dihasilkan, tercermin peradaban manusia pendukungnya. Sebagai pranata sosial, sastra mencerminkan ekpresi penghayatan dan pengalaman batin si pencerita atau pengarang terhadap pengarang atau situasi tertentu. Sastra selalu mengalami perkembangan seiring dengan perubahan zaman dan munculnya pemikiran-pemikiran baru dalam setiap aspek kehidupan. Hal ini juga berlaku dalam dunia sastra. Aspek kesejajaran akan memperlihatkan gambaran yang jelas dari ilmu sastra dari dahulu hingga sekarang. Secara metodologis penelitian ini menggunakan penelitian kepustakaan atau library research. Objek kajian pada penelitian ini adalah karya-karya sastra sufi. Pendekatan yang digunakan dalam penelitian ini adalah deskriptif kualitatif, di mana penelitian ini mendeskripsikan tidak dimaksudkan untuk menguji hipotesis tertentu. Karya sastra dengan cirikhas religious akan dapat mengarahkan pembacanya untuk menjadikan hati nurani lebih serius, shaleh dan teliti dalam pertimbangan batin. Sehingga karya sastra yang bersifat religious membuat pembacanya termenung dan berkotemplasi.
\end{abstract}

Kata Kunci: sastra; sufi; pesan religius, 


\section{PENDAHULUAN}

Karya sastra akan memiliki pesan sesuia dengan latar belakang penulisnya. Untuk melihat kedalaman makna dan pesan diperlukan tentan Pembahasan berikut merupakan penjelasan tentang hakikat pengertian, definisi dan karekteristik sastra sufi-religius dan hubungan karya sastra dengan agama. Pembahasan ini dilengkapi dengan contoh kutipan teks dan analisis singkat dari sastra sufi-religius. Menurut The World Book Dictionary kata religiosity berarti religius feeling or sentiment, atau perasaan keagamaan. Penjelasan ini mungkin telalu singkat. Agar tidak terlalu singkat mari kita kemabali kepada kepada akar kata religion yang sering kita salin menjadi religi, bukan agama.

Menurut Kamus Latin-Indonesia, susunan K. Prent C.M., J. Adisubrata dan W.J.S. Poerwadaminta, istilah religio berasal dari bahasa Latin yaitu relego, yang berarti: memeriksa lagi, menimbang-nimbang merenungkan keberatan hati nurani. Jadi, dapat dikatakan bahwa religi berarti merenungkan dalam hati manusia. (Mangunwijaya Y.B, 1988 :11) Menurut Cicereo relego Qui omnia quae ad cultum deorum partinerent, dilegenter retractarent et tamquam relegerent, sunt dicti religiosi. (orang disebut religius bila rajin mempelajari dan seolah serba tahu tentang segala yang berkaitan dengan kebaktian para dewa). Jadi. dapat dikatakan orang yang religius adalah orang yang menjalankan dan medalamkan suatu ajaran agama.

Sedangkan menurut The Wordl Book Dictionary (Chicago: 1982) (dalam Mangunwijaya1988:11) kata religious feeling or sentiment, atau perasaan keagamaan. Tetapi apa arti yang persis dari kata religio orang hanya dapat menduga. Sebab ada yang berpendapat, bahwa kata religio datang dari kata religio $=$ menambatkan kembali. Dari beberapa pendapat di atas bahwa sastra religi adalah sastra yang mengandung nilai-nilai agama di dalamnya, baik dapat diterima maupun tidak oleh kalangan di masyarakat.

Menurut Wachid B.S (2002:176) seorang yang religius adalah mereka yang mencoba mengerti hidup dan kehidupan secara pribadi dari kehidupan ini, dan mentaransedensikan hidup. Jadi dapat dikatakan bahwa orang yang religius adalah orang yang taat terhadap ajaranajaran agama yang diyakininya. Karya sastra sufi-religius merupaka karya sastra yang membuat pembaca merenung dan mengilhami karya tersebut. Menurut Hasjmy (1986:48-49) religiusitas adalah fitrah manusia yang berwujud dalam bentuk kesadaran jiwa paling dalam tentang hakikat dirinya, akan secara keseluruhan, dan tujuan hidup sesungguhnya. Karya sastra yang religius dapat membuka cakrawala berfikir para pembacanya untuk melakukan kontempalasi yang dalam berdasarkan norma-norma yang berlaku dan ada hubungannya dengan dimensi religiusitas yang dimiliki oleh Muhammad (dalam Hoerip,1982: 138-140)

Dari beberapa pendapat di atas maka sastra religi adalah sastra yang didalamnya mepersoalkan dimensi kehidupan manusia dalam kaitannya dengan dimensi trasedental yang puncaknya adalah Allah SWT melalui tubuh hati. Menurut Mangunwijaya (1988: 12) religiusitas lebih melihat aspek yang di dalam lubuk hati, riak getaran hati nurani pribadi; sikap personal yang lebih sedikit banyak misteri bagi orang lain, karena menapaskan intmitas jiwa, dan karena itu, pada dasarnya religiusitas mengatasi, atau lebih dalam dari agama yang tampak, formal, resmi.Pengalaman religi seorang penyair didasarkan atas pengalaman hidup penyair secara konkret. Jika penyairnya bukan seorang yang khusyuk dalam hal religi, maka sulit diharapkan ia akan menghasilkan puisi bertema ketuhanan secara mendalam (Waluyo, 1991:107). 


\section{METODE PENELITIAN}

Secara metodologis penelitian ini menggunakan penelitian kepustakaan atau library research. Objek kajian pada penelitian ini adalah karya-karya sastra sufi. Pendekatan yang digunakan dalam penelitian ini adalah deskriptif kualitatif, di mana penelitian ini mendeskripsikan tidak dimaksudkan untuk menguji hipotesis tertentu, tetapi hanya menganalisis isi makna yang terkandung dalam tulisan tersebut.

Data yang digunakan adalah metode dokumentasi. Yaitu suatu suatu tehnik pengumpulan data dengan menyelidiki benda-benda tertulis seperti buku-buku, majalah-majalah artikel, majalah, jurnal, web (internet), ataupun informasi lainnya yang berdasarkan kajian yang akan diteliti.

Untuk mendapatkan data dilakukan tiga tahap, yaitu tahap orientasi, tahap eksplorasi, dan tahap penelitian terfokus. Pertama, tahap orientasi, yaitu penulis menggunakan data secara umum yang berkenaan dengan tulisan karya sastra sufi. Kedua, tahap eksplorasi, yaitu pengumpulan data dilakukan lebih terarah sesuai dengan fokus studi. Fokus studi tersebut adalah melihat maknamakan yang terkandung dalam karya sastra sufi. Ketiga, tahap studi terfokus, yaitu penulis mulai melakukan studi secara mendalam yang terfokus pada masalah keberhasilan, keunikan dari karya sastra sufi.

Analisis yang digunakan dalam penelitian ini adalah analisis isi (content analysis). Di mana data deskriptif sering hanya dianalisis menurut isinya, dan karena itu analisis macam ini juga disebut analisis isi (content analysis). (Sumadi Suryabrata, 1983 : 94).

Analisis isi hanya meneliti atau menjelaskan data yang diambil dari sebuah paragraf dari tulisan seseorang. Sehingga analisis ini dibatasi hanya pada isi dari data yang akan dikutip. (Soejono dan Abdurrahman, 1999 : 14). Analisis isi yang dimaksud adalah bagaimana peneliti melihat keajegan isi komunikasi secara kualitatif, dan bagaimana peneliti memaknakan isi karya sastra sufi. Pada hakikatnya, analisis isi ini adalah salah satu model analisis yang digunakan peneliti dalam mengungkap, mengetahui, dan memahami isi dari literatur yang sudah dibaca. Dengan begitu, penulis akan dengan mudah menempatkan data mana yang sesuai dengan kebutuhan penulisan dan penelitian.

\section{HASIL DAN PEMBAHASAN}

Pembahasan berikut merupakan penjelasan tentang hakikat pengertian, definisi dan karekteristik sastra sufireligius dan hubungan karya sastra dengan agama. Pembahasan ini dilengkapi dengan contoh kutipan teks dan analisis singkat dari sastra sufireligius. Menurut The World Book Dictionary kata religiosity berarti religius feeling or sentiment, atau perasaan keagamaan. Penjelasan ini mungkin telalu singkat. Agar tidak terlalu singkat mari kita kemabali kepada kepada akar kata religion yang sering kita salin menjadi religi, bukan agama.

Menurut Kamus Latin-Indonesia, susunan K. Prent C.M., J. Adisubrata dan W.J.S. Poerwadaminta, istilah religio berasal dari bahasa Latin yaitu relego, yang berarti: memeriksa lagi, menimbang-nimbang merenungkan keberatan hati nurani. Jadi, dapat dikatakan bahwa religi berarti merenungkan dalam hati manusia. (Mangunwijaya Y.B, 1988 :11) Menurut Cicereo relego Qui omnia quae ad cultum deorum partinerent, dilegenter retractarent et tamquam relegerent, sunt dicti religiosi. (orang disebut religius bila rajin mempelajari dan seolah serba tahu tentang segala yang berkaitan dengan kebaktian para dewa). Jadi. dapat dikatakan orang yang religius adalah orang yang menjalankan dan medalamkan suatu ajaran agama.

Sedangkan menurut The Wordl Book Dictionary (Chicago: 1982) (dalam 
Mangunwijaya, 1988:11) kata religious feeling or sentiment, atau perasaan keagamaan. Tetapi apa arti yang persis dari kata religio orang hanya dapat menduga. Sebab ada yang berpendapat, bahwa kata religio datang dari kata religio $=$ menambatkan kembali. Dari beberapa pendapat di atas bahwa sastra religi adalah sastra yang mengandung nilai-nilai agama di dalamnya, baik dapat diterima maupun tidak oleh kalangan di masyarakat.

Menurut Wachid B.S (2002:176) seorang yang religius adalah mereka yang mencoba mengerti hidup dan kehidupan secara pribadi dari kehidupan ini, dan mentaransedensikan hidup. Jadi dapat dikatakan bahwa orang yang religius adalah orang yang taat terhadap ajaranajaran agama yang diyakininya. Karya sastra sufi-religius merupaka karya sastra yang membuat pembaca merenung dan mengilhami karya tersebut. Menurut Hasjmy (1986:48-49) religiusitas adalah fitrah manusia yang berwujud dalam bentuk kesadaran jiwa paling dalam tentang hakikat dirinya, akan secara keseluruhan, dan tujuan hidup sesungguhnya. Karya sastra yang religius dapat membuka cakrawala berfikir para pembacanya untuk melakukan kontempalasi yang dalam berdasarkan norma-norma yang berlaku dan ada hubungannya dengan dimensi religiusitas yang dimiliki oleh Muhammad (dalam Hoerip,1982: 138-140)

Dari beberapa pendapat di atas maka sastra religi adalah sastra yang didalamnya mepersoalkan dimensi kehidupan manusia dalam kaitannya dengan dimensi trasedental yang puncaknya adalah Allah SWT melalui tubuh hati. Menurut Mangunwijaya (1988: 12) religiusitas lebih melihat aspek yang di dalam lubuk hati, riak getaran hati nurani pribadi; sikap personal yang lebih sedikit banyak misteri bagi orang lain, karena menapaskan intmitas jiwa, dan karena itu, pada dasarnya religiusitas mengatasi, atau lebih dalam dari agama yang tampak, formal, resmi.Pengalaman religi seorang penyair didasarkan atas pengalaman hidup penyair secara konkret. Jika penyairnya bukan seorang yang khusyuk dalam hal religi, maka sulit diharapkan ia akan menghasilkan puisi bertema ketuhanan secara mendalam (Waluyo, 1991:107).

Akhir abad ke-16 hingga abad ke-17 pengaruh sastra dan budaya Islam baru tampak dalam sastra Melatu ataupun sastra Jawa. Dalam budaya Melayu Islam diterima sebagai unsur yang memperkaya, mendramatisir, serta mengangkat derajat sastra melayu menjadi cukup berkembang. Sementara di Jawa masuknya Islam dan penggunaan sastra sebagai media dakwah dipelopori oleh para wali (walisongo). Sunan Kalijogo, Sunan Bonang, Sunan Ampel memakai kesenian tradisional Jawa abad ke-16 masih buta huruf bukanlah penghalang bagi para wali dalam melakukan siar Islam (Tohari dkk 1998:20).

Adapun beberapa pengarang sufireligius tahun 70-an antara lain: Abdul Hadi WM, Danarto, Kuntowijoyo, Sutardji Calzoum Bachri, Emha Ainun Nadjib, Hamid Jabar, M. Fudoli Zlmi, dan beberapa pengarang tahun 80-an seperti: Ahmadun Yosi Herfonda, Isbedy Stiawan, Soni Farid Maulana, Acep Zamzam Noor, dan Endang Supriydi . Dan masih banyak lagi para pengarang sastra sufi-religius yang terus berkembang hinggga sekarang.

Beberapa karya sastra yang beraliran sufi-religius adalah Cerpen-cerpen Danarto "Setangkai Melati Disayap Jibril" Cerpen AA Navis" Robohnya Surau Kami”, Karya Hamzah Fansuri "Syair Perahu" Sutardji dalam pengantar Kumpulan puisi" Amuk Kapak", puisi Amir Hamzah " Nyanyian Sunyi”,Danarto “Godlob" dan masih banyak para penyair yang menciptakan karya sastra beraliran religi.Menurut Mangunwijaya (1988:144) cerpen-cerpen Danarto adalah parableparabel religius, cerita-cerita kiasan 
kaum kebatinan, yang luar biasa dinamika dan daya imajinasinya.

Najib (1994) mengungkapkan dunia sastra adalah salah sat jalur terikat yang bisa berarti lansung perjalanan kesejahteraan batin Tuhan maupun sekaligus kontribusi-kontribusi sosial atau sama sekali "tak berurusan dengan Tuhan ". Najib membaggi bentuk sastra dari sudut religiusitas- hubungan Tuhan tersebut dalam empat bagian yautu sastra sekuler, sastra diniyah, sastra Islami, dan sastra Nabuwwah.

1. Sastra sekuler (secara subyektif) mengorientasikan diri ke dalam suatu kesadaran "kosmos tanpa Tuhan", meski (secara objektif) tetap produk dari kenyataan social. Hingga hasil karya sastra sekulersama sekali tidak mustahil utuk bersifat religious.

2. Sastra diniyah adalah sastra religius. Sebuah karya sastra yang sengaja atau tidak sengaja mengaitkan diri dari dengan dimensi ketuhanan. Sastra diniyah dapat lahir dari kosmos teologis agama-agama atau diluar itu.

3. Sastra islami adalah suatu kerja kesusatraan dalam suatu rangka kesadaran nilai keislaman, baik formal maupun informal, eksplisit maupun implisit: kerangka anatomi nilainya leebih 'tertentu' dibanding sastra diniyah.

4. Sastra Nubuwwah (profetik) adalah suatu jenis karya sastra yang meletakkan komitmen sosial sebagai substansi tematik. Target-targetnya berada dalam lingkungan hidup sosial kultural.

Agama mempunyai peranan penting dalam penciptaan suatu karya sastra. Seperti yang dinyatakan oleh Semi (1984:14) agamalah yang merupakan ambang pintu bagi segenap kesusastraan agung di dunia. Agamalah yang merupakan sumber filsafat yang selalu mengudik kepadanya.

Contoh Teks yang beraliran sufi-
religius 1. Contoh teks 1
Sebagai contoh dari sastra sufireligius, penulis mengutip sebuah cerpen AA Navis yang berjudul Robohnya Surau Kami. Adapun kutipunnya sebagai berikut:

"Sadari mudaku aku di sini, bukan? Tak kuingat punya istri, punya anak, punya keluarga seperti orang-orang lain, tahu? Tak kupikirkan hidupku sendiri. Aku tak ingin cari kaya, bikin rumah. Segala kehidupanku, lahir batin, keserahkan kepada Allah Subhanahu wataala. Tak pernah aku menyusahkan orang lain. Lalat seekor enggan aku membunuhnya. Tapi kini aku dikatakan manusia terkutuk. Umpan neraka. Marahkah Tuhan kalau ini yang kulakukan, sangkamu? Akan dikutukinya aku kalau selama hidupku aku mengabdi kepada Nya? Tak kupikirkan hari esokku, karena aku yakin Tuhan itu ada dan pengasih dan penyayang kepada umatNya yang tawakal. Aku bangun pagi-pagi. Aku berrsuci. Aku pukul beduk membangunkan manusia dari tidurnya, supaya bersujud kepada-Nya. Aku sembahyang setiap waktu, siang malam, pagi sore. Aku karuniaNya. "Astagfirullah, kataku bila aku kagum. Apakah salahnya pekerjaanku itu? Tau kini aku dikatakan manusia terkutuk."

"Pada suatu waktu, 'kata Ajo Sidi memulai,' di akhirat Tuhan Allah memeriksa orang-orang yang sudah berpulang. Para malaikat berugas di sampingNya. Di tangan mereka tergenggam daftar dosa dan pahala manusia. Begitu banyak orang-orang diperiksa. Maklumlah di mana-mana ada perang. Dan diantara orang yang diperiksa itu ada seorang yang di dunia dinamai Haji Saleh. Haji Saleh itu tersenyum-senyum saja, karena ia sudah begitu yakin akan dimasukkan ke surga. Kedua tangannya ditopangnya di pinggang sambil membusungkan dada dan menekurkan kepala ke duduk . ketika dilihatnya orang-orang yang masuk neraka, bibirnya menyunggingkan senyum ejekan. 
"Ya, Tuhanku, tak ada pekerjaanku selain daripada beribadat menyembah$\mathrm{Mu}$, menyebut-nyebut nama-Mu. Bahkan dalam kasih-Mu, ketika aku sakit, namaMu menjadi buah bibir juga. Dan aku juga selalu berdoa, mendoakan kemurahan hati-Mu untuk menginsafkan umat-Mu.

"sudah hamba-Mu ceritakan semuanya, o, Tuhan yang Mahabesar, lagi pengasih dan penyayang, adil dan mahatahu.'Haji Saleh yang sudah kuyu mencobakan siasat merendahkan diri dan memuji dengan pengharapan semoga Tuhan bisa berbuat lembut terhadapnya dan tidak salah Tanya kepadanya.

Tapi Tuhan bertanya lagi: 'Tak ada lagi?

“0,o,ooo, anu Tuhanku. Aku selalu membaca kitab-Mu.'

'Lain?' Sudah kuceritakan semuanya, o, Tuhanku. Tapi kalau ada yang aku lupa mengatakannya, aku pun bersyukur karena engkaulah mahatahu..'

'sungguh tidak ada lagi yang kaukerjakan di dunia selain yang kuceritakan tadi?

'Ya, itulah semuanya, Tuhanku.'

'Masuk kamu.'

'Ya, Tuhanku, tak ada pekerjaanku selain daripada beribadat menyembah $\mathrm{Mu}$, menyebut-nyebut nama Mu. Bahkan dalam kasih $\mathrm{Mu}$, ketika aku sakit, nama Mu menjadi buah bibir juga. Dan aku juga.

\section{Contoh teks 2}

Karya Abdul Hadi WM, adapun kutipan puisi sebagai berikut:

Tuhan, Kita Begitu Dekat

Tuhan

Kita begitu dekat

Sebagai api dengan panas

Aku panas dalam apimu

Tuhan

Kita begitu dekat

Seperti kain dengan kapas

Aku kapas dalam kainmu

Tuhan

Kita begitu dekat
Seperti angin dan arahnya

Kita begitu dekat

Dalam gelap

Kini aku nyala

Pada lampu padamu (Abdul Hadi,WM)

\section{Contoh teks}

Contoh teks ketiga kumpulan puisi 0 , Amuk Kapak Karya Sutardji Calzoum Bachri, yang berjudul walau

Walau

Walau penyair besar

Takkan sampai sebatas Allah

Duu pernah kuminta Tuhan

Dalam diri

Sekarang tak

Kalau mati

Mungkin

Matiku bagai batu tamat bagai pasir tamat

Jiwa membumbungdalam baris dan sajak

Tujuh puncak membilang-bilang

Nyeri hari mengucap-ucap

Di butir pasir kutulis rindu

Walau huruf habislah sudah

Alifbataku belum sebatas Allah

(O, Amuk, Kapak,1981:107)

\section{ANALISIS TEKS}

\section{Analisa teks 1}

Cerita pendek yang berjudul Robohnya Surau Kami karya AA Navis ini mengungkapkan kejadian di dunia akhirat yang sebenarnya belum pernah kita rasakan. Adapun kutipannnya sebagai berikut:

"'Pada suatu waktu, kata Ajo Sidi menulai, di akhirat Tuhan Allah memeriksa orang-orang yang sudah berpulang. Para malaikat bertugas di samping-Nya. Di tangan mereka tergenggam daftar dosa dan pahala manusia".

Dari cuplikan menggambarkan keadaan dunia akhirat yang akan kita 
tempuh. Jadi pengarang menceritakan kegiatan yang ada di dunia akhirat yang akan kita jalani natinya. Jadi, dapat dikatakan membahasa karya satra dari segi religiusitas berarti membicarakan hal yang sangat mendasar dari dimensi kehidupan yang diungkapkan oleh pengarang dalam karyanya.

Menurut Hasanuddin (1991:12) karya sastra yang religious akan dapat mengarahkan pembacanya sebagai hati nurani serius, shaleh dan teliti dalam pertimbangan batin. Sehingga karya sastra yang bersifat religious membuat pembacanya termenung dan berkotemplasi. Dapat dilihat dalam kutipannya sebagai berikut:

"Aku beri kau negeri yang kya raya, tapi kau malas. Kau lebih suka beribadat saja, karena beribadat tidak mengeluarkan peluh, tidak membanting tulang. Sedang aku menyuruh engkau terus beribadat. Bagaimana engkau bisa beramal kalau engkau miskin. Engkau kira aku ini suka pujian, mabuk disembah saja.Tidak. Kamu semua mesti masuk neraka. Hai, malaikat, halaulah mereka ini kembali ke neraka. Letakkan mereka di keraknya".

Dari cuplikan teks di atas mempunyai amanat, bahwa pesan selain mementingkan dunia akhirat harus mementingkan dunia duniawi. Dari cerita pendek di atas menceritakan seorang Haji Saleh, yang di dunia terus taat terhadap agama, kesehariannya selalu mengaji dan beribadah. Tetapi malaikat-malaikat Allah SWT, mengatakan bukankah Allah SWT, selain beribadah kita sebagai manusia harus saling tolong menolong terhadap sesama.

Amanat yang disampaikan di dalam cerpen Robohnya Surau kami adalah kita sebagai umat manusia selain menjalankan perintah Allah SWT, dan menjaukan segala larangannya. Selain beriabadah tetapi rasa toleransi terhadap sesama jangan kita lupakan.

\section{Analisis teks 2}

Abdul Hadi WM sebagai salah seorang sastrawan Indonesia yang meletakkan akar tradisi dalam puisi-puisi yang berakar pada khazanah sufisme. Salah satu puisinya yang berjudul Tuhan Kita Begitu Dekat. Puisi ini menggambarkan hubungan kita terhadap Tuhan tidak lah dapa dipisahkan. Kita sebagai umat yang selalu meminta pertolongan dan perlindungan terhadapNya. Tidak henti-hentinya selalu meminta terhadap Tuhan. Pagi dan siang malam kita selalu ingin dekat kepadanya.

\section{Analisis Teks 3}

Pada kutipan puisi di atas, hubungan trasendental manusia- Tuhan dinyatakan penyair ini sebagai hubungan yang misterius, gaib dan penuh tabir rahasia. Kerahasian dan kegaiban hubungan ini yang dikaitkan dengan zat Tuhan merupakan masalah yang tidak dapat dipecahkan oleh logika manusia. kenyataan ini menimbulkan rasa keingintahuan manusia besar. Manusia berusaha untuk menyingkap tabir rahasia Tuhan, kegaiban Tuhan serta kemisteriusan Tuhan.

\section{KESIMPULAN}

Karya sastra dengan cirikhas religious akan dapat mengarahkan pembacanya untuk menjadikan hati nurani lebih serius, shaleh dan teliti dalam pertimbangan batin. Sehingga karya sastra yang bersifat religious membuat pembacanya termenung dan berkotemplasi.

Puisi-puisi yang berakar pada khazanah sufisme menggambarkan hubungan kita terhadap Tuhan tidak lah dapat dipisahkan, hubungan trasendental manusia dengan Tuhan dinyatakan oleh penulisnya sebagai hubungan yang misterius. 


\section{DAFTAR KEPUSTAKAAN}

Bagus, Lorens. 2002. Kamus Filsafat. Gramedia: Pustaka.

Chittck, William C. 2001. The Sufi Path Knowledge Pengetahuan Spritural Ibnu Al-Araby.Yogyakarta: Qalam

Hasanudin WS. 1992."Resepsi Kreatif Unsur Religiusitas Penyair Utama Kesustraan Indonesia Modern" (Pusat Penelitian IKIP Padang)

Mangunwijaya Y.B. 1988. Sastra dan Religiositas. Yogyakarta: Kanisius.

Najib, Emha Ainun. 1994. Terus Mencoba Budaya Tanding. Pustaka

Pelajar:Yogyakarta.

Wachid B.S. 2002. Alam Religiositas. Yogyakarta: Gama Media.

Semi, M. Atar. 1984. Anatomi Sastra. Padang: Sridharma.

Tohari,Ahmad dkk. 1998. Sastra dan Budaya Islam Nusantara: Yogyakarta: Kalijaga. 